\title{
Microstructure Evolution and Phase Transformation of FeWB Based Cermets During the Vacuum Sintering
}

\author{
Yu Hongwei ${ }^{1}, \quad$ Li Jun ${ }^{1,2}, \quad$ Li Cheng ${ }^{1}, \quad$ Liu Ying ${ }^{1,2}$ \\ ${ }^{1}$ Sichuan University, Chengdu 610065, China; ${ }^{2}$ Key Laboratory of Advanced Special Material and Technology, Ministry of Education, Chengdu \\ 610065, China
}

\begin{abstract}
The FeWB based cermets were produced by the reaction boronizing sintering at different temperatures and with different holding time. The influences of temperature and holding time on the phase transformation, microstructure of cermets as well as the reaction mechanism were investigated by X-ray diffraction meter (XRD), scanning electron microscopy (SEM) and energy disperse spectroscopy (EDS). The results show that the hard phase FeWB is produced in the compact at the stage of solid phase sintering by the reaction $\mathrm{W}+\mathrm{Fe}_{2} \mathrm{~B}=\mathrm{FeWB}+\mathrm{Fe}$ and $\mathrm{W}+\mathrm{FeB}=\mathrm{FeWB}$. Besides, the $\mathrm{FeWB}$ phase exhibits an equiaxed morphology. The distinctly rapid densification occurs at the temperature ranging from 800 to $1150{ }^{\circ} \mathrm{C}$. When the temperature exceeds $1300{ }^{\circ} \mathrm{C}$, the FeWB phase transforms to $\mathrm{Fe}_{7} \mathrm{~W}_{6}$ phase, which results in the further improvement of the density. With the increase of temperature, the cermets prepared by liquid phase sintering exhibit a relatively homogenous microstructure, accompanied by in situ growth of thick FeWB grains. In order to obtain a higher density, the sintering temperature of preparing FeWB based cermets should be controlled between 1150 and $1250{ }^{\circ} \mathrm{C}$. Moreover, it is necessary to appropriately increase the content of iron and ferro-boron.
\end{abstract}

Key words: FeWB based cermets; reaction boronizing sintering; phase transformation; densification

For industrial application, wear resistant materials should have a wide range of properties such as high strength, high toughness, corrosion and oxidation resistance, electrical and thermal conductivity. Borides, especially transition metal borides, possess high hardness, high melting points and high electrical conductivity among hard materials. It was a promising candidate as wear resistant material and it has been intensively studied while the outstanding properties of borides also has been widely documented. However, the previous studies showed that borides had poor sinterability. It was extremely brittle and had strong reactivity with metals, which were notorious disadvantages to form solid structures. It was the key technological challenges in processing and fabrication of borides by powder metallurgy.

FeWB material possesses superior properties of transition metal boride, excellent thermal stability and high theoretical density, which is impressing and should be highlighted. Based on our previous study, the new kind transition metal boride FeWB could broaden the scope and accelerate the development in this exciting research domain $^{[1,2]}$. In addition, H. Haschke and A. Leithe-Jasper had widely researched the phase diagram and crystal structure of $\mathrm{FeWB}^{[3,4]}$. Therefore, FeWB was anticipated to present significant potential in extensive fields such as used as hard material, wear resistant material and high temperature resistant material.

In this paper, we mainly researched the effect of reaction boronizing sintering on FeWB based cements. Reaction boronizing sintering was a novel strategy to form a ternary boride coexisting with a binder metal during liquid phase sintering ${ }^{[5]}$. This sintering technique was used to develop some ternary boride base cermets with excellent mechanical properties, wear and corrosion resistance, such as $\mathrm{Mo}_{2} \mathrm{FeB}_{2}-\mathrm{Fe}^{[6]}, \mathrm{Mo}_{2} \mathrm{NiB}_{2}-\mathrm{Ni}^{[7-11]}$ and WCoB-Co ${ }^{[12]}$. It was applied to inject machine parts, make can tools and prepare hot copper extruding dies. However, 
scant attention was paid to FeWB since it was an emerging ternary boride. One of the most important reason is associated with the scarce and unevenly distributed resource of tungsten, while China produces about $85 \%$ of the world production of tungsten ore ${ }^{[13]}$. Besides, the phase transformation and microstructure evolution are important to determinate the sintering process due to its notable effect on the mechanical properties. Therefore, in this study, the FeWB phase was prepared by vacuum sintering at different temperatures and with different holding time. The phase transformation and microstructure evolution were studied by scanning electron microscopy (SEM) and X-ray diffraction analysis (XRD).

\section{Experiment}

The commercial ferro-boron powders $(19.65 \mathrm{wt} \% \mathrm{~B})$ obtained by mechanical crushing from ferro-boron bulk, tungsten powders $(99.95 \mathrm{wt} \% \mathrm{~W})$ with a mean size of $3.0 \sim 4.0 \mu \mathrm{m}$ and ferrous powder $(99.95 \mathrm{wt} \% \mathrm{Fe})$ were used as the raw materials. The nominal compositions of Fe-68W-4.0B (wt\%) was used for the present investigation.

The ferro-boron, iron and tungsten powders were mixed in a rotary ball-mill in ethanol together with cemented carbide balls for $48 \mathrm{~h}$ at a speed of $80 \mathrm{r} / \mathrm{min}$. After milling, the slurries were dried at $70{ }^{\circ} \mathrm{C}$ in a vacuum drying oven. Then the alloy powders were pressed into green compacts with dimensions $40 \mathrm{~mm} \times 8 \mathrm{~mm} \times 8 \mathrm{~mm}$ at $100 \mathrm{MPa}$ for $10 \mathrm{~s}$. The samples were prepared in SDZK furnace ranging from $400{ }^{\circ} \mathrm{C}$ to $1350{ }^{\circ} \mathrm{C}$ without holding under argon atmosphere in order to obtain information on the crystalline phase and microstructures at different sintering temperatures.

The phases of the powders and ceramics were examined by X-ray diffraction (XRD) using $\mathrm{Cu} \mathrm{K} \alpha$ radiation (DX-2000, Fangyuan, China) in the range of $10^{\circ} \sim 100^{\circ}(2 \theta)$ and operated at $40 \mathrm{kV}$ with a scan rate of $0.06^{\circ} / \mathrm{s}$. The microstructure was observed by a JSM-6490LV scanning electron microscopy (SEM), and the microscopic region composition analysis was carried out using the GENESIS 2000 XMS energy dispersive X-ray spectrometry (EDS) system which was attached to the SEM. The bulk density of the sintered specimens were measured using the geometry method at low temperature $\left(\leq 1150{ }^{\circ} \mathrm{C}\right)$. At higher temperatures, the bulk density of the sintered specimens were determined by Archimedes' method.

\section{Results and Discussion}

\subsection{Crystalline phases}

XRD patterns of the samples at different sintering temperatures without holding are shown in Fig.1. The phases of samples synthesized at $400{ }^{\circ} \mathrm{C}$ are composed of only $\mathrm{FeB}, \mathrm{W}$ and $\mathrm{Fe}$. When the temperature is further
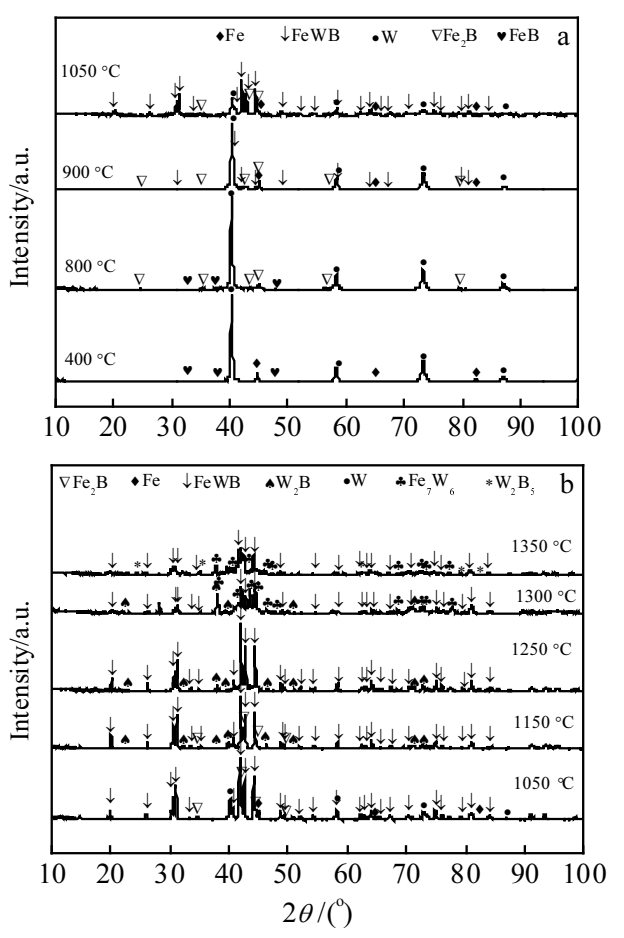

Fig.1 XRD patterns of the samples at different sintering temperatures without holding: (a) low temperature and (b) high temperature

increased to $800{ }^{\circ} \mathrm{C}$, the phase changes to $\mathrm{Fe}_{2} \mathrm{~B}, \mathrm{FeB}$ and $\mathrm{W}$ phase. Further increasing temperature to $900{ }^{\circ} \mathrm{C}$, the FeWB begins to appear, and the peak intensity of $\mathrm{W}$ is obviously weakened. After synthesizing at $1050{ }^{\circ} \mathrm{C}$, the phase almost changes to $\mathrm{FeWB}$ with some $\mathrm{W}$ and $\mathrm{Fe}_{2} \mathrm{~B}$ coexisting. When the temperature is increased to $1050{ }^{\circ} \mathrm{C}$, the peak intensity of FeWB increases slightly while some $\mathrm{W}_{2} \mathrm{~B}$ phase appears. At a higher sintering temperature, from $1250{ }^{\circ} \mathrm{C}$ to $1350{ }^{\circ} \mathrm{C}$, the peak intensity of $\mathrm{FeWB}$ phase is obviously weakened. Particularly at $1350{ }^{\circ} \mathrm{C}$, the $\mathrm{Fe}_{7} \mathrm{~W}_{6}$ and $\mathrm{W}_{2} \mathrm{~B}_{5}$ phases could be observed clearly. It could be concluded that when the temperature reaches up to $1350{ }^{\circ} \mathrm{C}$, the FeWB phase has been transformed which results in the decrease of peak intensity of FeWB. Fig.2 is the XRD patterns of the samples at various sintering temperatures from $900{ }^{\circ} \mathrm{C}$ to $1350{ }^{\circ} \mathrm{C}$ with holding for $1 \mathrm{~h}$. It could be seen that when the temperature reaches to $1250{ }^{\circ} \mathrm{C}$, the $\mathrm{Fe}_{7} \mathrm{~W}_{6}$ phase appears. Moreover, the FeWB phase disappears when the temperature reaches up to $1350{ }^{\circ} \mathrm{C}$. The result shows that the reasonable reaction boronizing sintering temperature range should be controlled between 1050 and $1250{ }^{\circ} \mathrm{C}$ for preparing FeWB phase.

According to the analysis above, we could conclude that the FeWB phase is formed during the sintering process. However, the definite formation mechanisms are unclear. 


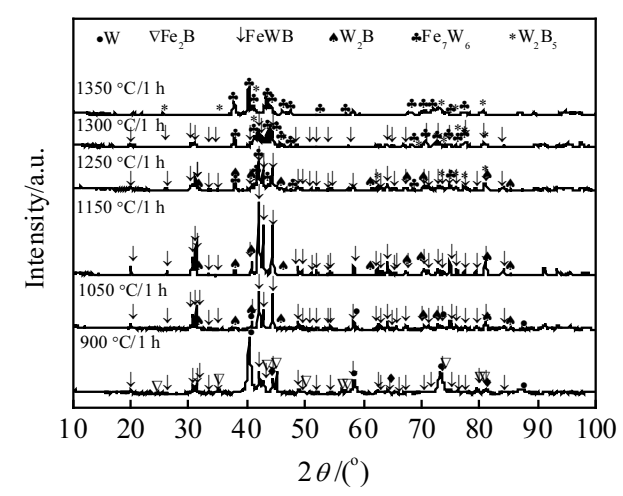

Fig.2 XRD patterns of the samples at various sintering temperatures with holding $1 \mathrm{~h}$

As mentioned above, the $\mathrm{Fe}_{2} \mathrm{~B}$ phase appears before the formation of the FeWB phase based on the stoichiometry of the direct reaction $\mathrm{Eq}(1)$ or indirect reaction $\mathrm{Eq}(2)$ :

$$
\mathrm{W}+\mathrm{FeB} \rightarrow \mathrm{FeWB}
$$

$$
\mathrm{W}+\mathrm{Fe}_{2} \mathrm{~B} \rightarrow \mathrm{FeWB}+\mathrm{Fe}
$$

Based on the research of Jialin $\mathrm{Li}^{[1]}$, there was no peak of FeWB occurring when the sintering temperature was $1050{ }^{\circ} \mathrm{C}$ without holding. Therefore, it could be deduced that a higher sintering temperature or driving force is needed for the reaction of $\mathrm{Eq}(1)$. Besides, it could be seen that the reaction of $\mathrm{Eq}(1)$ is essentially for further reaction into $\mathrm{Fe}_{2} \mathrm{~B}$ and $\mathrm{W}_{2} \mathrm{~B}$ by $\operatorname{Eqs}(3)$ and (4). This is the reason why the synthesis of FeWB phase needs some heat preservation time at $1050{ }^{\circ} \mathrm{C}$.

$\mathrm{FeB}+\mathrm{W} \rightarrow \mathrm{Fe}_{2} \mathrm{~B}+\mathrm{W}_{2} \mathrm{~B}$

$\mathrm{Fe}_{2} \mathrm{~B}+\mathrm{W}_{2} \mathrm{~B} \rightarrow 2 \mathrm{FeWB}$

Besides, the result of Jialin Li's research showed that using the $\mathrm{FeB}$ and $\mathrm{W}$ to synthesize the FeWB phase was feasible. Consequently, the FeWB phase could be formed by this two kinds of reaction processes. When the temperature is low, the reaction by $\operatorname{Eq}(2)$ is the main one. With the increase of temperature, this two kinds of reaction by Eqs(1) and (2) process would occur at the same time. In addition, FeWB phase transforms into $\mathrm{Fe}_{7} \mathrm{~W}_{6}$ when the temperature is higher than $1300{ }^{\circ} \mathrm{C}$. It may be related to the existence of $\mathrm{W}_{2} \mathrm{~B}$ phase and excessive ferrous presented in the raw material. On the one hand, $\mathrm{W}_{2} \mathrm{~B}_{5}$ is more stable than $\mathrm{W}_{2} \mathrm{~B}$ at high temperatures based on the thermodynamics ${ }^{[14]}$. On the other hand, at high temperature, the diffusion coefficient of boron in tungsten is larger than that of boron in $\gamma$-Fe. When the temperature is between 1100 and $1900{ }^{\circ} \mathrm{C}$, the diffusion coefficient of boron in tungsten is $2.62 \times 10^{-5} \exp (-15300 / T)^{[15]}$, and the diffusion coefficient of boron in $\gamma$-Fe is $2 \times 10^{-7} \exp (-0.91 / k T)^{[16]}$. With the FeWB phase transformed into $\mathrm{Fe}_{7} \mathrm{~W}_{6}$, the rest of the boron atoms could diffuse into the $\mathrm{W}_{2} \mathrm{~B}$ phase. Therefore, the $\mathrm{W}_{2} \mathrm{~B}$ phase has the potential to transform into $\mathrm{W}_{2} \mathrm{~B}_{5}$. Based on the above analysis, it could be deduced that the reaction by $\mathrm{Eq}(5)$ might occur in this process.

$$
12 \mathrm{FeWB}+3 \mathrm{~W}_{2} \mathrm{~B}+\mathrm{Fe} \rightarrow 2 \mathrm{Fe}_{7} \mathrm{~W}_{6}+3 \mathrm{~W}_{2} \mathrm{~B}_{5}
$$

\subsection{Densification}

Fig. 3 shows the average density of the FeWB based cermets at different sintering temperatures without holding. It could be seen that the density has no obvious increcement with the temperature increasing from 400 to $800{ }^{\circ} \mathrm{C}$. However, the extremely rapid densification occurs with the temperature changing from 800 to $1150{ }^{\circ} \mathrm{C}$, which is mainly attributed to the occurrence of the $\mathrm{Fe}$ and $\mathrm{Fe}_{2} \mathrm{~B}$ liquid phases $^{[17]}$. When the temperature further increases from 1150 to $1250{ }^{\circ} \mathrm{C}$, the density is almost invariant and the density of the cements exceeds $11 \mathrm{~g} / \mathrm{cm}^{3}$. When the sintering temperature is higher than $1250{ }^{\circ} \mathrm{C}$, the density increases significantly. It is mainly due to the disappearance of FeWB phase by translating to other phases such as $\mathrm{Fe}_{7} \mathrm{~W}_{6}$ and $\mathrm{W}_{2} \mathrm{~B}_{5}$. In consequence, based on the above analysis, the best temperature of liquid phase sintering should be controlled between 1150 and $1250{ }^{\circ} \mathrm{C}$ in order to obtain better density of FeWB based cermets.

\subsection{Microstructure}

Fig.4 shows the SEM micrographs of the samples synthesized at different temperatures without holding and EDS results of points in Fig.4a 4e. It could be seen from Fig.4a that the samples retain the characteristics without significant sintering when the sintering temperature is 800 ${ }^{\circ} \mathrm{C}$, even though there should be slight changes associated with the formation of $\mathrm{Fe}_{2} \mathrm{~B}$ phase. When the temperature increases to $900{ }^{\circ} \mathrm{C}$, the number of small particles has been significantly reduced. When the temperature increases to $1050{ }^{\circ} \mathrm{C}$, the surface of the particles changes to be a little smooth. Besides, almost all of the small particles are spread into larger particles. When the temperature further increases to $1250{ }^{\circ} \mathrm{C}$, the morphology of particles changes very smooth. The fine facets are found when the atom ratio of $\mathrm{W} / \mathrm{Fe}$ is close

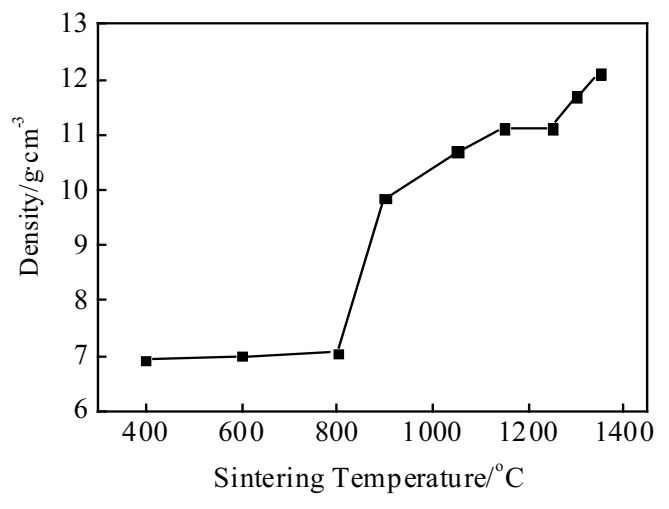

Fig.3 Effects of sintering temperature on density of the FeWB based cermets without holding 

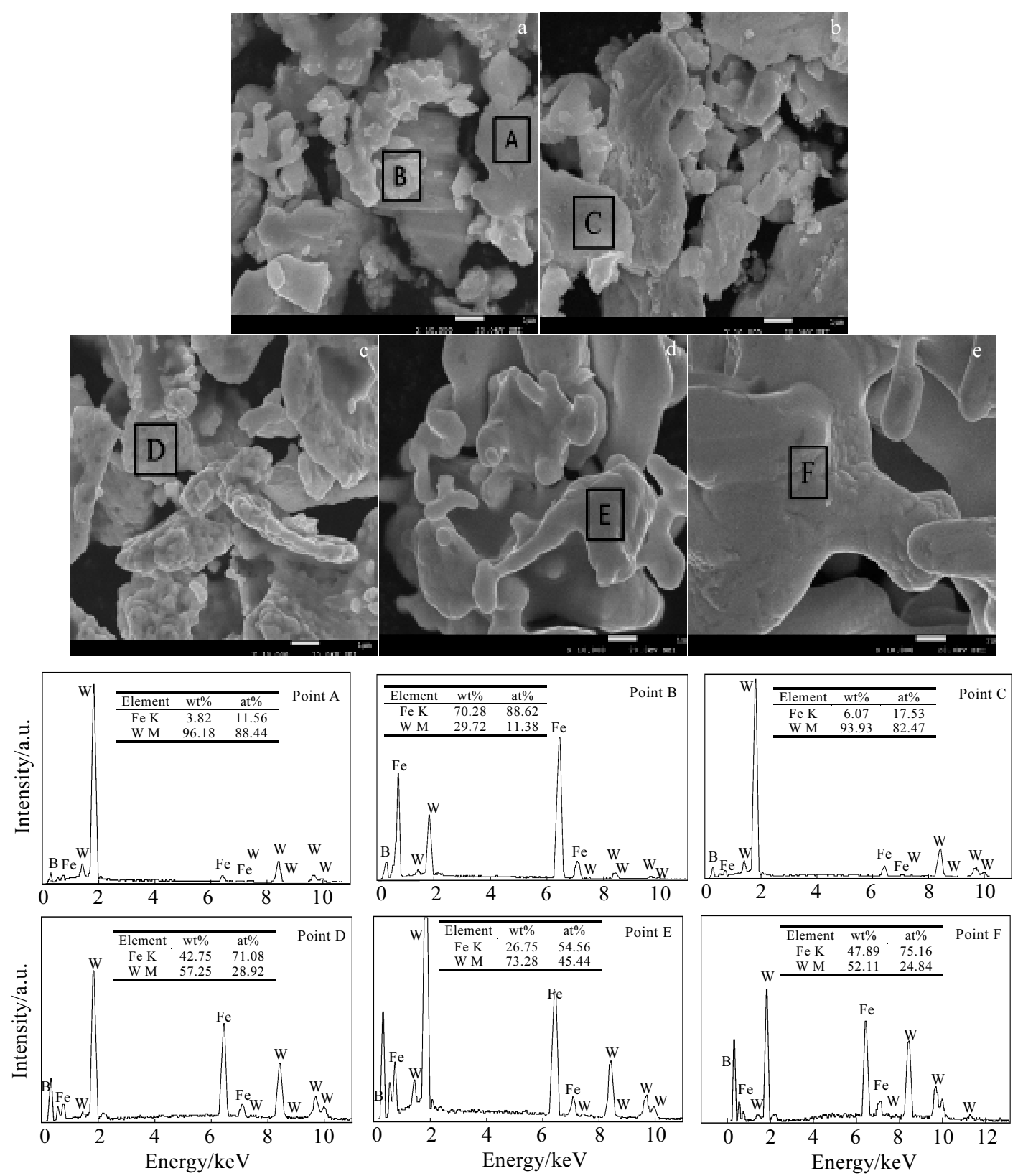

Fig.4 SEM micrographs of the samples synthesized at different sintering temperatures without holding and EDS result of points marked in Fig.4: (a) $800{ }^{\circ} \mathrm{C}$, (b) $900{ }^{\circ} \mathrm{C}$, (c) $1050{ }^{\circ} \mathrm{C}$, (d) $1250{ }^{\circ} \mathrm{C}$, and (e) $1350{ }^{\circ} \mathrm{C}$

to $1: 1$ by EDS, which are identified as FeWB grains with the aid of the XRD results. When the temperature increases to $1350{ }^{\circ} \mathrm{C}$, the morphology of particles grows up remarkably and the smoothness of surface decreases significantly with many small particles precipitating from surface. By the results of XRD and EDS, it could be determined that the FeWB phase has changed.

Fig. 5 shows the microstructures of the cermets prepared by liquid phase sintering at different temperatures. We could see uneven distribution of the microstructure by the agglomeration of the binder phase and a higher contiguity of the hard phase. When the temperature is lower than 1050 ${ }^{\circ} \mathrm{C}$, the liquid phase sintering characteristics is not obvious. When the sintering temperature further increases to $1250{ }^{\circ} \mathrm{C}$, the cermet exhibits a relatively homogenous microstructure accompanies by an in situ growth of thick FeWB grains.

Fig. 6 shows the typical microstructures of the cermets sintered for different soaking time when the sintering temperature is $1250{ }^{\circ} \mathrm{C}$. It shows that the increment of holding time promotes the growth of FeWB grains significantly when the temperature is $1250{ }^{\circ} \mathrm{C}$ while the growth of the FeWB phase is associated with the grain 


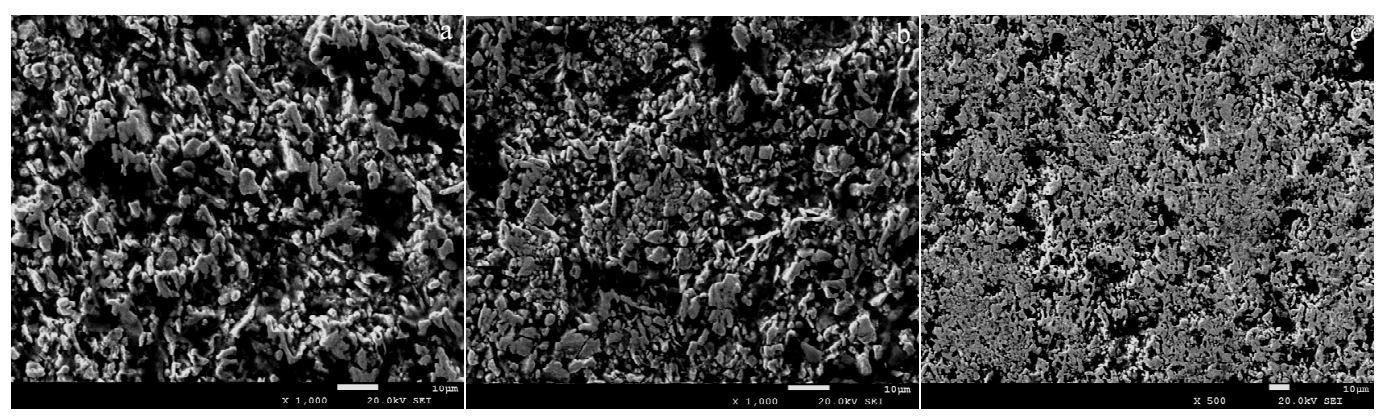

Fig.5 Microstructures of the cermets prepared at different sintering temperatures: (a) $1050{ }^{\circ} \mathrm{C}$, (b) $1150{ }^{\circ} \mathrm{C}$, and (c) $1250{ }^{\circ} \mathrm{C}$

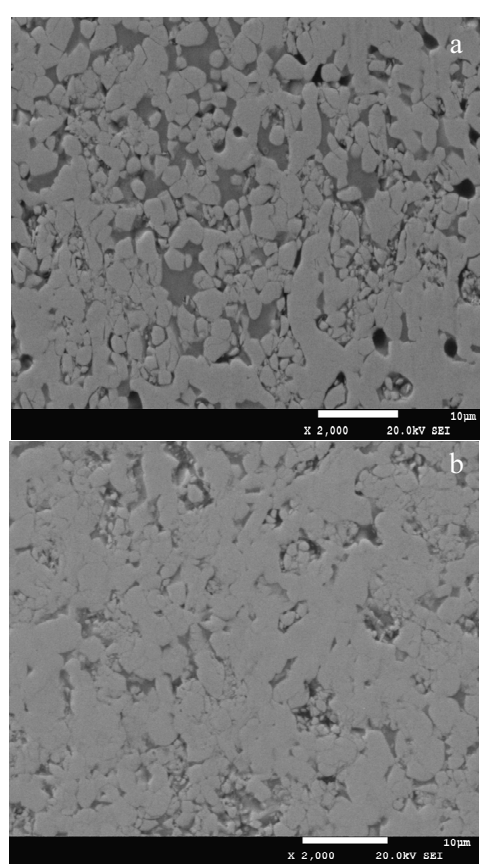

Fig.6 Microstructures of the cermets sintered at $1250{ }^{\circ} \mathrm{C}$ for different soaking time: (a) $20 \mathrm{~min}$ and (b) $40 \mathrm{~min}$

coalescence. In addition, the visible porosity is observed and the compactness is only about $93 \%$ compared with the theoretical density due to the lack of binding phase. Therefore, increasing the content of iron and ferro-boron and reducing the content of tungsten in the mixed powder is very essential.

\section{Conclusions}

1) FeWB based cermet can be preliminary obtained by reaction boronizing sintering with optimal synthesis temperature between 1150 and $1250{ }^{\circ} \mathrm{C}$ while the density of the bulk almost remains invariability and the surface morphology of the particles is very smooth.

2) The formation of FeWB is originated from the reaction of $\mathrm{Fe}_{2} \mathrm{~B}+\mathrm{W}=\mathrm{FeWB}+\mathrm{Fe}$ and $\mathrm{FeB}+\mathrm{W}=\mathrm{FeWB}$ during the solid phase sintering. However, the former reaction mechanism is the main part due to its lower energy requirement.

3) When the temperature is higher than $1300{ }^{\circ} \mathrm{C}$, the FeWB phase decomposes via the reaction of $12 \mathrm{FeWB}+$ $3 \mathrm{~W}_{2} \mathrm{~B}+2 \mathrm{Fe}=2 \mathrm{Fe}_{7} \mathrm{~W}_{6}+3 \mathrm{~W}_{2} \mathrm{~B}_{5}$ and the surface morphology of particles shows many precipitates.

4) The visible porosity is observed and the compactness is only about $93 \%$ compared with the theoretical density due to the lack of binding phase.

5) Increasing the content of iron and ferro-boron and reducing the content of tungsten in the mixed powder is very essential.

\section{References}

1 Li J L, Li J, Li C. International Journal of Refractory Metals \& Hard Materials[J], 2014, 46(1): 80

$2 \mathrm{Li} \mathrm{C}$, Li J L, Li J et al. Advanced Powder Technology[J], 2015, 26(5): 1410

3 Haschke H, Nowotny H, Benesovsky F. Monatshefte Für Chemie Und Verwandte Teile Anderer Wissen-schaften[J], 1966, 97(5): 1459

4 Leithe-Jasper A, Klesnar H, Rogl P. Journal of the Japan Institute of Metals[J], 2000, 64(2): 154

5 Takagi K, Komai M, Matsuo S. European Powder Metallurgy Association[J], 1994, 1: 227

6 Rao D, Upadhyaya G S. Materials Chemistry \& Physics[J], 2001, 70(70): 336

7 Yuan B, Zhang G J, Kan Y M et al. International Journal of Refractory Metals and Hard Materials[J], 2010, 28(2): 291

8 Takagi K, Yamasaki Y, Komai M. Journal of Solid State Chemistry[J], 1997, 133(1): 243

9 Komai M, Yamasaki Y, Takagi K I et al. Advances in Powder Metallurgy[J], 1992, 8: 81

10 Takagi K. Materials Chemistry and Physics[J], 2001, 67(1): 214

11 Takagi K. Cheminform[J], 2006, 179(9): 2809

12 Takagi K, Ohira S, Ide T et al. Met Powder Rep[J], 1987, 42: 
483

13 Takagi K I, Koike W, Ai M et al. Solid State Sciences [J], 2012, 14(11-12): 1643

14 Duschanek H, Rogl P. Journal of Phase Equilibria[J], 1995, 16(2): 150
15 Gromilov S A, Kinelovskii S A, Alekseev A V et al. Journal of Structural Chemistry[J], 2010, 51(51): 1126

16 Busby P E, Warga M E, Wells C. Trans AIME[J], 1953, 197: 1463

17 Ide T, Ando T. Metal Mater Trans A[J], 1989, 20: 17

\title{
FeWB 基陶瓷在真空烧结过程中的组织演变和相转变
}

\author{
余虹位 ${ }^{1}$, 李 军 ${ }^{1,2}$, 李 程 ${ }^{1}$, 刘 颖 ${ }^{1,2}$ \\ (1. 四川大学, 四川 成都 610065)
}

(2. 先进特种材料与技术教育部重点实验室, 四川 成都 610065)

\begin{abstract}
摘 要: 研究了烧结温度和保温时间对反应嗍化烧结制备 FeWB 基陶瓷的影响。利用 $\mathrm{X}$ 射线衍射, 扫描电镜和能谱仪对 FeWB 基陶瓷 烧结过程中的相转变, 微观组织以及反应机理进行了表征。结果表明, $\mathrm{FeWB}$ 硬质相是通过 $\mathrm{W}+\mathrm{Fe}_{2} \mathrm{~B}=\mathrm{FeWB}+\mathrm{Fe}$ 和 $\mathrm{FeB}+\mathrm{W}=\mathrm{FeWB}$ 两种 方式合成的, 并且反应生成的 $\mathrm{FeWB}$ 晶粒呈等轴形貌。在 800 1150 ${ }^{\circ} \mathrm{C}$ 之间, $\mathrm{FeWB}$ 基陶瓷的密度骤然升高, 这与 $\mathrm{Fe}_{2} \mathrm{~B}$ 相的熔化有关。 在 $1300{ }^{\circ} \mathrm{C}$ 时, 由于 $\mathrm{W}_{2} \mathrm{~B}$ 相的存在, 会使 $\mathrm{FeWB}$ 相转变为 $\mathrm{Fe}_{7} \mathrm{~W}_{6}$ 相, 从而使密度进一步升高。随着烧结温度的提高, 通过液相烧结制 备的金属陶瓷表现出相对均匀的微观结构, 而且原位合成的 FeWB 颗粒会发生长大。为了获得较高的致密度, FeWB 基陶瓷的烧结温 度应控制在 1150 1250 ${ }^{\circ} \mathrm{C}$ 之间。其次, 适当的增加铁和硼铁的含量有利于烧结的致密化。
\end{abstract}

关键词: FeWB基陶瓷; 反应硼化烧结; 相转变; 致密化

作者简介: 余虹位, 男, 1990 年生, 硕士生, 四川大学材料科学与工程学院, 四川 成都 610065, 电话: 028-85405332, E-mail: yexingla@live.com 